\title{
Jukka Sarjala
}

\section{Halu on sielun jalca}

\section{Musiikin voima ja affektit varhaisella uudella ajalla}

Yllä olevan lausuman halusta esitti saksalainen teologi Johann Gerhard, luterilaisen puhdasoppisuuden merkittävä edustaja, kirjassa Meditationes sacrae (1606). Kirja julkaistiin myös suomeksi otsikolla Pyhät Tutkistelemuxet Turussa vuonna 1688. Sananparresta tuli meilläpäin varsin suosittu; se kuului varhaisten pietistien kielenkäyttöön. (Huhtala 1971, 113.) Sen lisäksi, että se kuvaa uskonnollisen reformiliikkeen uutta hurskausihannetta, omakohtaisen tuntemisen vaatimusta, siihen tiivistyy keskeinen osa länsimaisen moraalifilosofian perinnettä. Lause sanoo, että ihmisen tahdon, toimintamuotojen ja tekojen perusta on halussa. Halu merkitsee tässä yksilön spontaania kykyä tulla liikutetuksi ja aktiiviseksi jonkin havaitun tai kuvitellun tekijän tai objektin voimasta. Tehdäkseen jotakin ja liikkuakseen jollakin tavalla - ajatusten, tunteiden tai ruumiinliikkeiden muodossa - ihmisen on elettävä yleisessä halullisuuden tilassa. Ei tarvita kovin laaja-alaista ja pitkäaikaista kokemusta sen seikan tunnustamiseen, että musiikki tuottaa, lisää ja ylläpitää halua niin ihmisissä kuin eläimissä. Musiikin liike muuntuu ruumiillisiksi liikkeiksi ja virkistää fantasiaa. Tämä kiihdyttää halun kantajaa tiettyyn suuntaan, kohti nopeita ja eloisia tuntemuksia tai hitaita ja pieniä liikahduksia.

Artikkelini ei käsittele pietistien musiikkikäsityksiä tai -kulttuuria, jotka kyllä ansaitsisivat Suomessakin enemmän huomiota Suvi-Päivi Kosken tekemän väitöskirjan (1996) ohella. Tarkastelen sen sijaan muutamia tärkeitä puolia ja näkökohtia 1600- ja 1700-luvulla vaikuttaneesta affektiopista ja siihen kohdistuneesta tutkimuksesta. Musiikin affektioppi oli keskeisiltä osin teoriaa halun synnystä ja säätelystä, ihmisten toiminnallisuudesta. Affektit olivat voimia, jotka oikein käytettyinä kohensivat yksilön hyvinvointia ja aktiivisuutta mutta myös järjestivät ihmisten välisiä suhteita ja yhteisöllisyyttä. Kirjoitukseni valottaa aihepiiriä siltä pohjalta, mitä olen siitä löytänyt ja esittänyt hiljattain ilmestyneessä monografiassani musiikin, moraalin ja ruumiillisuuden suhteista uuden ajan alkupuolen Turussa ja siellä virinneissä opillisissa pohdinnoissa (Sarjala 2001). Kovin yksityiskohtaiseen tarkasteluun en voi tässä yhteydessä ryhtyä. Asiasta enemmän tietoa haluavien on syytä tutustua kirjaani tai katsoa tarkemmin kirjoitukseni lähdeluetteloa. 


\section{Affektitutkimuksen kaksi suuntausta}

Affektit, passiot ja musiikin aikaansaamat tunneliikkeet näyttävät muodostavan modernille länsimaiselle musiikkitieteelle ja musiikin estetiikalle uhkaavan toiseuden, josta on vaiettu melkein kaksi vuosisataa. John Shepherd ja Peter Wicke toteavat kirjassaan Music and Cultural Theory, että musiikkitiede on ollut huomattavan menestyksetön kehittämään käsitteitä ja teorioita, jotka selittäisivät, miksi musiikki viehättää ihmisiä arkipäivän askareissa. Musiikintutkijat eivät ole laajemmin tarkastelleet, miksi musiikilla on voimaa ja vaikutusta ihmisiin. Shepherdin ja Wicken mukaan musiikkitiede on jatkuvasti vältellyt kysymyksiä vaikutuksista ja merkityksistä. Sen sijaan se on pitänyt kiinni tavoitteestaan luoda tosiasioita kohteestaan ja sen historiasta. (Shepherd \& Wicke 1997, 7.) Fred Everett Maus on puolestaan kirjoittanut siitä, miten musiikinteoreetikot, jotka ovat useimmiten olleet miehiä, ovat omaksuneet kontrolloivan ja ennakointiin perustuvan asenteen musiikin hahmottamisessa. Musiikin aktiivinen ja aloitteellinen rooli mielihyvän tuottajana on hävinnyt; tilalle ovat nousseet rationalisointi ja hallinta. Teoreetikoille on ollut luontevaa olla käsittelemättä musiikin aikaansaamaa mielihyvää, koska kuuntelukokemukseen sisältyvän aistimellisuuden esiintuominen sisältää ajatuksen kuulijasta musiikkia passiivisesti vastaanottavana osapuolena, feminiinisyyden edustajana. (Mausin näkemyksistä ks. esim. Leppänen 2000, 90, 92.)

Musiikin hallintaan ja aistimellisen aineksen rationalisaatioon liittyvät kokemukset, järjestyksen kaipuun ja ennakoinnin tarpeen tyydyttäminen, ovat toki aikaansaaneet mielihyvää. Mutta useat musiikkitieteilijät ovat tulkinneet tämän kaltaisen mielihyvän paljon arvokkaammaksi kokemisen lajiksi, tieteellisen havaitsemisen ja päättelyn taustatekijäksi. Tutkijan tai asiantuntijan saavuttama kliininen etäisyys omaan aistimellisuuteensa ja musiikin herättämiin tuntemuksiin on tuottanut iloa ja tyydytystä. Musiikin ja ihmisen salaiset voimat ovat kontrollissa. Ennen 1990-lukua, ennen Susan McClarya (1991) ja Suzanne G. Cusickia (1994), halu ei ole ollut hyväksyttävä ja keskustelua jäsentävä kategoria musiikkianalyysissa tai musiikinteoriassa.

Yllä todetun rinnalle on mahdollista nostaa ituja ja esiintymiä toisenlaisesta tutkimusperinteestä tai paradigmasta. Nämä idut eivät ole musiikkitieteen sisällä kuitenkaan kyenneet perusteellisesti horjuttamaan länsimaisen musiikinteorian rakentamaa suurta kertomusta, tulkintaa musiikin taideluonteesta ja konstruktiivisuudesta. Musiikin tuottaman halun ja mielihyvän tutkiminen on varsinaisesti saanut alkunsa viimeaikaisen kulttuurintutkimuksen, populaarimusiikin tutkimuksen ja feministisen musikologian myötä. Mutta asiaan kiinnittivät huomiota jo 1900-luvun alkuvuosikymmenien saksalaiset musiikkitieteilijät ja musiikillisen hermeneutiikan edustajat (Hermann Kretzschmar 1912 ja 1913; Hugo Goldschmidt 1915/1968; Arnold Schering 1939 ja 1941; Rudolf Schäfke 1924). Historiallinen tilanne ja tutkimuksen tavoitteet 
olivat tuolloin kovin erilaiset parin viimeisen vuosikymmenen aikana vallinneeseen tilanteeseen verrattuna. Affekteista ja tunnetilojen representaatioista kiinnostuneet 1900luvun alkupuolen musiikkitieteilijät, joihin lukeutui ennen pitkää muitakin kuin saksalaisia, eivät analysoineet kohteitaan halua ja mielihyvää koskevan teoretisoinnin varassa. He käsittelivät musiikkia tunteita kuvaavana ja aiheuttavana kielenä, jolla oli oma kielioppinsa ja sanastonsa, figuurit. Musiikin tulkintaa ja ymmärtämistä tuli edistää selittämällä, millaisista osasista ja merkityksiä sisältävistä yksiköistä soiva aines koostui. Joka tapauksessa nämä musiikintutkijat näyttivät suuntaa musiikin ruumiillisten vaikutusten, kuulijoissa aiheutettujen tunnetilojen ja ihmisessä näiden kautta syntyvän eloisuuden ja liikkeen tarkastelulle.

Musiikin aikaansaamia tunteita ovat tutkineet niin psykologit kuin kognitiotieteilijät, mutta heidän lähestymistavoillaan ja tuloksillaan on ollut varsin vähän tekemistä historiallisesti suuntautuneen tunnetutkimuksen kanssa. Jälkimmäinen tutkimusperinne on musiikkia koskevalta osalta jaettavissa karkeasti ottaen kahtia. Yhtäältä musiikkitieteilijät ovat pyrkineet analysoimaan ja osoittamaan retoriikan oppien hengessä enemmän tai vähemmän osuvia vastaavuuksia musiikin elementtien ja erilaisten tunnetilojen välillä. Näin he ovat menetelleet etenkin barokkimusiikin tutkimuksessa (esim. Butt 1994; Bartel 1997). Ajatuksena on ollut, että musiikin ainekset ja ominaisuudet - figuurit, harmoniset muutokset, rytmit, melodiset kulut yms. - representoivat 1600- ja 1700-luvulla erityyppisiä tunteita. Ne saivat tuollaiseen musiikilliseen kieleen perehtyneen kuulijan vastaaviin tunnetiloihin. Musiikki kuvasi tunteita; kuvausten elävyys ja havainnollisuus aiheutti kuulijoissa erilaisia mielentiloja. Kiistaa on käyty siitä, oliko selviä vastaavuuksia ollenkaan olemassa ja voivatko tutkijat jälkikäteen tunnistaa musiikin elementeistä ja osasista tunteiden esittämis- ja tuottamiskeinoja.

Toisaalta musiikin ja tunteiden tutkijat ovat paneutuneet asian ei-semioottiseen puoleen eli varhaisella uudella ajalla paljon viljeltyyn ajatukseen musiikin sisältämästä voimasta ja liikkeestä (vis \& motus). Nimitän sitä ei-semioottiseksi ulottuvuudeksi sen takia, että siinä musiikin yksityiskohtainen merkkiluonne ja kommunikatiivisuus jäävät taka-alalle. Tärkeiksi tulevat kysymykset musiikin sielullis-ruumiillisista vaikutuksista ja sosiaalis-poliittisista merkityksistä yhteiskunnassa. Johtava idea tässä näkökulmassa on, että koska musiikilla tosiasiassa on ollut ja on edelleen kouriintuntuvia vaikutuksia, on mielekkäämpää tarkastella noiden vaikutusten kulttuurihistoriallisia ehtoja ja seuraamuksia kuin ryhtyä pohtimaan sitä, miten musiikillisia yksityiskohtia olisi tulkittava. Musiikin voiman ja vaikutuksen tarkastelijoille kiinnostavaa on ollut musiikkia käyttäneiden ihmisten passiossa oleminen, tunteiden ja kokemusten tapahtumaluonne ja suoranainen materiaalisuus. Ensin mainittu, musiikin merkkien tulkinnasta kiinnostunut tutkimussuuntaus rakentuu paljolti musiikkianalyysin, sävellystekniikoiden tuntemuksen ja musiikin valmistamista (poiesis) koskevan tietämyksen varaan. Jälkimmäisessä suuntauksessa tutkijat taas työskentelevät käsitehistorian, uuden ajan alkupuolen tunne- ja havaintoteorioiden, tietojärjestelmien 
historian sekä tunteiden historiallisen etnografian parissa. Kirjoitan tässä artikkelissa jälkimmäisestä.

\section{Passio versus tunne}

Affektioppi, josta ryhtyivät ensimmäiseksi puhumaan yllä mainitut saksalaiset musiikkitieteilijät, on varhaisen uuden ajan musiikkikulttuurin "suuri teoria". Se on 1600- ja 1700-luvun Euroopassa laajalle levinnyt ja yhteisesti jaettu peruskatsomus musiikista, sen sisältämistä voimista ja ominaisuuksista. Vastaavankaltainen paradigma toisessa kontekstissa on keskiajalla kannatettu Boethiuksen teoria musiikin kolmesta eri tasosta tai lajista, planeettajärjestelmän musiikista (musica mundana), yksilön sieluruumiissa konstituoituvasta musiikista (musica humana) ja ihmisen esittämästä, korvin kuultavissa olevasta musiikista (musica instrumentalis). Toinen affektioppia kattavuutensa ja keskustelua ohjanneen voimansa osalta muistuttava diskursiivinen muodostelma löytyy 1800-luvun taidemusiikin estetiikasta. Se perustui olennaisilta osin hengen ja aistimellisuuden väliseen kahtiajakoon, jossa musiikkia eroteltiin idealistiseen muotoon sekä materiaalis-fyysiseen olemassaoloon ja vaikutukseen. (Boethiuksesta esim. Abert 1964, 164-165; Schäfke 1982, 39; kategorioista Geist ja Sinnlichkeit ks. Sponheuer 1987, 9-35, 168-175.)

Musiikin affekteja koskevasta, 1600- ja 1700-luvulla laajalle levinneestä yhteisymmärryksestä huolimatta myöhemmät tutkijat eivät ole kyenneet osoittamaan kovin yhtenäisen ja pitkälle systemoidun affektiteorian olemassaoloa (esim. Buelow 1983, 397, 403-404). Ankara opillisuus lienee tässä tapauksessa saksalaisten musiikkitieteilijöiden jälkikäteistä aikaansaannosta. Yhtä kaikki, lähes aina kun musiikista kirjoitettiin varhaisella uudella ajalla, kirjoittajien oli vaikea sivuuttaa kysymystä affekteista ja musiikin vaikutuksesta (efficacia). Tämä näkyy jopa musiikkia koskeneen, 1600-luvulla vielä elinvoimaisena vaikuttaneen pythagoralaisen lukuteorian taustalla. Musiikin matemaattisten ominaisuuksien ja rakenteiden tarkastelu ei perustunut vakaumukseen, että tieto noista seikoista olisi ollut arvokasta sinänsä. Päinvastoin, teoreetikot ja oppineet paneutuivat musiikin lukusuhteisiin juuri siksi, että he katsoivat musiikilla olevan niiden ansiosta konkreettisia ja materiaalisia vaikutuksia ihmiseen. Filosofi René Descartes $(1618 / 1992,2)$ aloitti ensimmäisen kirjallisen työnsä, pienen matemaattisen tutkielman musiikista, toteamalla, että musiikin tarkoitus on miellyttää ja herättää kuulijoissa erilaisia passioita.

Kiinnostukseni musiikin aiheuttamiin vaikutuksiin ja tunneliikkeisiin sai alkunsa halusta osoittaa, millä tavoin 1600- ja 1700-luvun Euroopan säätymuotoiselle elämänjärjestykselle ominaiset kokemisen ja tuntemisen tavat - affektit, passiot ja tunteikkuus - erosivat moderneista, 1800- ja 1900-luvulle tyypillisistä autonomisen tunteen, 
sentimentaalisuuden tai itseilmaisun muodoista. Ensin ajattelin, että asettaisin vastakkain kaksi tai mahdollisesti kolme erilaista tunnetiloihin asettautumisen tapaa, nimittäin barokin kiivaat affektit, 1700-luvun jälkipuolen lempeän tunneherkkyyden ja varhaisromantikkojen "sanoin kuvaamattomat", ilmaisujen ulottumattomissa olevat tunteet. Tällaisessa tutkimusasetelmassa olisin voinut tarkastella tunteiden ja tunnemuotojen muuttuvuutta parinsadan vuoden kuluessa. Suunnitelma oli ylimitoitettu eikä välttämättä kovin lupaava. Aihepiiriin tutustuessani huomasin, että affektiopin, tunneherkkyyden ja romantikkojen suosimien ylevien tunteiden tutkimus on muualla maailmassa tuottanut jo muutaman keskikokoisen kirjaston verran kirjoja ja artikkeleita. Perehtyminen affektioppiin ja tunneherkkyyden historiaan ohjasi kiinnostukseni musiikin ja moraalin väliseen suhteeseen sekä tämän suhteen mahdollistavan ruumiillisen perustan tarkasteluun. 1600- ja 1700-luvulla musiikki tunnustettiin avoimesti poliittiseksi ja ihmistä muokkaavaksi voimaksi. Hyvä elämänjärjestys kasvoi esiin yksilöiden ruumiillisen olemisen muokkaamisesta ja kontrollista.

Laajasti ymmärrettynä affekti (affectus, passio, Leidenschaft) tarkoitti mitä tahansa mielenliikettä tai tunnetilaa ja sen ruumiillisia puolia. Latinankielinen partisiipin perfekti affectus juontuu verbistä afficere. Se merkitsee vaikuttamista, tuottamista, vaikutuksen aiheuttamista, jonkun saattamista johonkin tilaan jne. Affekti-sanalla on siis viitattu psyykkis-fyysisiin vaikutuksiin ja olotiloihin, jotka ovat aiheutuneet kokijalle ulkoisen tekijän tai ulkoisten tekijöiden johdosta. Piispa, Kuninkaallisen Turun Akatemian varakansleri ja kouluopetuksen ankara vartija Johannes Gezelius vanhempi määritteli Encyclopaedia synopticassa (1672) passion eli affektin korostaen tapahtumakulun ennakoimattomuutta. Passio oli "mielen tai ruumiin äkillinen muutos kuten viha tai pelosta aiheutunut kalpeus". Se oli "toiminnan vastaanottoa, jonka mukaan jotakin sanotaan kärsittävän". (Gezelius 1672 Pars prima, 16, 19.) Ihminen koki affektit tahdosta tietyssä määrin riippumattomiksi halujen liikkeiksi. Jos hän havaitsi ulkoisen tekijän tai objektin hyväksi, hänessä syntyi tavoittelun halu eli ilo tai rakkaus. Jos taas objekti oli paha tai vastenmielinen, seurauksena oli pakenemisen halu, joka ilmeni suruna tai pelkona. (Gyllenstålpe \& Myricius 1653, Thes: 8, 10, 13, 14.) Affektit olivat inhimillisen toiminnan perustavia liikevoimia, "mielen ratsuväki" niin kuin niitä Turun Akatemiassa kutsuttiin (ks. Haartman \& Kiellgren 1732, 31).

Retoriikka on käsitellyt affektien aikaansaamista ja hallintaa antiikin ajoista alkaen. 1700-luvun lopulle asti lukemattomat kirjoittajat ja oppineet kuvasivat affektin tai passion käsitteellä erilaisten merkkijärjestelmien, musiikin, kirjallisuuden, kuvataiteen tai puheen, aikaansaamia reaktioita ihmisessä. Näyttämöllä, kuvissa, teksteissä, musiikissa ja veistoksissa affekteja tuli esittää aristotelismin oppien mukaan selkeästi ja ideaalityyppisesti. Oli näytettävä kunkin tunnetilan yleinen forma, kunkin mielenliikkeen pysyvä muoto, josta kaikki yksittäiset arkimaailman affektit, passiot ja niiden representaatiot olivat muunnelmia. Havainnollisen esittämisen oli puolestaan määrä saattaa havaitsija tiettyyn tunnetilaan tai sellaisten vaihteluun. Tämä oli affectus ex- 
primere \& concitare -periaate. Idea sai 1600-luvun kuluessa humoraalipatologisia vivahteita. Lääketieteen alaan kuulunut humoraalipatologia käsitteli ihmisen ruumiinnesteiden (humores) koostumuksia, ruumiillis-psyykkisiä vaikutuksia ja nesteiden keskinäisiä suhteita. Uuden ajan alun mekanistisen luonnonfilosofian edustajat kehittelivät näkökulmia, joissa he tarkastelivat musiikin harmoniaa ja rytmiä ruumiinnesteiden ja elonhenkien (spiritus animales) liikuttajina. Tällaisten teorioiden mukaan musiikin liike muuntui ihmisruumiin saavuttaessaan nesteiden ja kehon kanavissa kulkevien lämpimien höyryjen sopusuhtaiseksi liikkeeksi. Näillä taas oli erilaisia vaikutuksia sieluun. Affekteja ja niiden representaatiomuotoja luokiteltiin runsaslukuisesti, musiikissakin ainakin 160 erilaista figuuria (ks. esim. Buelow 1980, 794-800). Mutta oppineet kävivät 1600- ja 1700-luvulla myös keskusteluja siitä, oliko musiikissa olemassa mitään yleisiä ja kaikkialla päteviä affektien aikaansaamisen tapoja (Thomas 1995, 20-33).

Affektit erosivat 1800- ja 1900-luvulla kukoistaneista tunteen, sentimentaalisuuden sekä itseilmaisun muodoista ja käsitteistä. Tämän eron taustalla on syvällekäyneitä muutoksia ajattelujärjestelmissä, kokemisen tavoissa ja ihmiskäsityksessä. Jo 1920luvulla Gotthold Frotscher $(1926,92)$ huomautti, ettei affekti ollut sama asia kuin tunne, Gefühl. Absoluuttisen musiikin estetiikka, joka oli saksalaisten romantikkojen keksintö, irtautui aiemmasta representaatioperiaatteesta. Romantikot kokivat ja ymmärsivät ihmisen tunneliikkeet ruumiillisuutta, materiaalisuutta ja luokittelua pakeneviksi sieluntiloiksi. (Braun 1994, 39.) Affektit ja passiot olivat olleet persoonattomia, tarkasti luokiteltuja ja kaikille yhteisiä liikevoimia, mutta tunteita käsiteltiin epätäsmällisinä, yksilökohtaisina ja yksityisinä ilmiöinä.

\section{Nimetön musiikki}

Kun tutustuin vanhoihin Turun Akatemiassa kirjoitettuihin musiikkidissertaatioihin tai Turun Soitannollisen Seuran juhlapuheisiin, en tavannut niissä muutamia nimiä lukuun ottamatta mainintoja musiikkiteoksista, tyyleistä tai säveltäjistä. Tekstien kirjoittajat eivät käsitelleet musiikkia teosten sarjana tai kokoelmana eivätkä pitäneet sitä suurten nerojen luomana taiteena. He eivät tehneet sen sisällöstä syvämietteisiä tulkintoja. Toisin kuin Beethovenin elinaikana ja varsinkin sen jälkeen, näissä teksteissä musiikki ei vaadi "ymmärtämistä". Se oli liikettä ja voimaa. Musiikki vaikutti niin ihmisiin kuin eläimiin, jopa elottomiin kappaleisiin, hämmästyttävällä tavalla. Esimodernilla ajalla oli hyvin tavallista käsitellä musiikin ihmevaikutuksia (miri effectus musicae, Wunderwirkungen). Akatemian pienten väitöskirjojen laatijat kertasivat tarinoita musiikin magiasta antiikin ajoilta ja historiasta, viittasivat joihinkin uudempiinkin tapahtumiin, siteerasivat Raamatun kertomusta raivoavasta Saul-kuninkaasta ja Daa- 
vidin parantavasta soitosta tai Raamattuun kuulumatonta tarinaa profeetta Elisan ekstaasista musiikin avulla (ks. Laurbecchius \& Forzelius 1680 Membrum secundum, 18; Rudeen \& Munck 1697, 54, 57-59; Alander \& Preutz 1703, 6-9; Bilmark \& Mechelin 1763, 15-16).

Musiikki oli yksi liikkeen laji muiden joukossa. Sen hämmästyttävät vaikutukset kuuluivat tuon ajan luonnonfilosofian tosiseikkoihin samalla tavoin kuin planeettojen liikkeet tai kasvien kasvaminen. Uuden ajan alkupuolen kirjallisuuden piiristä parhaimmat esimerkit ja elävimmät kertomukset näistä seikoista löytyvät Athanasius Kircheriltä, saksalaissyntyiseltä, suuren osan elämästään Roomassa asuneelta jesuiittakollegion professorilta. Ei olisi tieteenhistorian kannalta ollenkaan perusteetonta kääntää suomeksi, ehkä sentään lyhennettynä, joku hänen monista kirjoistaan, vaikkapa Musurgia universalis (1650), Iter exstaticum coeleste (1656) tai Phonourgia nova (1673). Kaikissa näissä hän on käsitellyt musiikkia enemmän tai vähemmän. Kircherin kirjoista, samoin kuin Turun Akatemian dissertaatioista, saa seikkaperäisen tuntuman siihen, miten tunteiden tarkastelu ja niiden syiden ja seurausten luonnonfilosofinen selittäminen oli uuden ajan alkupuolella vivahteikas sekoitus aristotelista liiketeoriaa, matematiikkaa, temperamenttioppia, humoraalipatologiaa, magiaa ja kartesiolaista mekaniikkaa.

Turkulaiset professorit ja ylioppilaat jäivät oppineisuudessa Kircheriä selvästi vaatimattomammiksi, mutta heidän kirjalliset aikaansaannoksensa eivät olleet musiikin suhteen mitenkään asiantuntemattomia. Eräissä keskusteluissa olen tosin havainnut, että moderni musiikinteoria ja tieteenfilosofia ovat muokanneet ja ohjanneet nykypolven tutkijoiden ja opiskelijoiden ennakkokäsityksiä siihen suuntaan, että joillakin on taipumus pitää näitä vanhoja opinnäytteitä alkeellisina ja epäitsenäisinä. Huomion kiinnittäminen kirjoitusten tieteelliseen tasoon ja laatuun siirtää tutkimuksen polttopisteen pois diskursiivisuudesta ja merkityksenmuodostumisesta ja antaa harhaanjohtavasti tilaa originaalisuuden ja tekijyyden ideoille. Sen sijaan että tutkija miettisi, kuka noista vuosisatoja sitten eläneistä kirjoittajista oli omintakeinen ja "uutta luova" ja kuka ei, hänen olisi parempi kohdistaa mielenkiintonsa siihen, mitä nuo professorit ja ylioppilaat tosiasiassa kirjoittivat ja mitkä asiat heitä tuolloin askarruttivat. Kuninkaallisessa Turun Akatemiassa ei kannustettu poikkeamaan virallisista opeista (Kallinen 1995, 20-21).

Akatemian musiikkidissertaatioissa sekä 1700- ja 1800-luvun vaihteen molemmin puolin Turun Soitannollisen Seuran vuosijuhlissa pidetyissä puheissa kirjoittajat ottivat osaa yleiseurooppalaiseen keskusteluun, joka koski musiikin moraalisia tehtäviä ja merkitystä. Musiikki herätti kiinnostusta affektiivisuutensa, ei taiteellisuutensa takia. Lähes aina kun 1600- ja 1700-luvun Turussa joku kirjoitti tai puhui musiikista ja affekteista, liikkeelle panevana voimana oli moraalinen tai poliittinen tiedonintressi. Musiikkiin sisältyvät voimat aiheuttivat yhtäältä kiihtymystä ja myllerrystä, toisaalta auttoivat ihmisten sivilisoimisessa ja yhteisön poliittisen järjestyksen ylläpidossa. Pro- 
fessoreita ja ylioppilaita askarrutti kysymys, miten tuollaisia tehokkaita, likipitäen vaarallisia voimia voitiin käyttää suotuisiin tarkoituksiin. Kirjoituksista näkee, että musiikin salaiset vaikutukset herättivät pelonsekaista kunnioitusta. Oli ihmeellistä ja suurenmoista, että pienillä ja melkein huomaamattomilla muutoksilla musiikissa oli dramaattisia ja syvällekäyviä vaikutuksia kuulijoissa. Juuri tuo huomaamattomuus ja vähäeleisyys oli magiaa, koska sen seuraukset näyttivät syntyvän melkein tyhjästä.

\section{Halu ja sen käsittely}

Affektioppi tarkasteli sielullis-ruumiillisten liikkeiden esittämisen ja aikaansaamisen keinoja ja menetelmiä, mutta yhtä paljon se oli teoriaa musiikin voimien vastaanotosta ja sen edellytyksistä. Musiikkia kuullessaan ihminen mukautui sen liikkeeseen sieluruumiinsa kykyjen ja taipumusten ehdoin. Silloin hän joutui tilanteeseen, jossa jotakin tapahtui ja avautui hänelle. Hän asettui alttiiksi jollekin; passio oli toiminnan kohteena olemista, voimien läpivirtaamista. Uuden ajan alkupuolella ihmisen ei katsottu laadullisesti tai olemuksellisesti eroavan muusta maailmanjärjestyksestä, vaan hän eli ja toimi itselleen ulkopuolisten voimien ja liikkeiden ehdoilla ja tuella. Moraali ei ollut niinkään yksilön vastuuta itselleen ja omalletunnolleen kuin yhteisön ylläpitämää halun kiihdyttämistä, vakauttamista ja sopiviin muotoihin ohjaamista. Tällaisissa olosuhteissa musiikki oli keino ylläpitää ja edistää yhteisön järjestystä. Oppineet pohtivat sitä, mitä ihmisessä tapahtui, kun hänen reagointitapojaan ja käyttäytymistään harjaannutettiin musiikilla moraalisesti ja poliittisesti suotuisaan suuntaan.

Musiikki ja etiikka oli ikivanha teema. Antiikin ajoista alkaen Euroopassa oli pidetty affekteja, esimerkiksi vihaa, pelkoa, iloa, rakkautta tai kateutta, joko ihmismielen satunnaisina häiriötiloina tai toimintaan kiihottavina virikkeinä. Tulkinta - arvioitiinko affektit siis kielteisiksi vai myönteisiksi ilmiöiksi - oli sidoksissa näkökulmaan. Stoalaisen näkökannan mukaan affekteja tuli ohjata ja hallita, jopa tukahduttaa järjen avulla, jotta ne eivät pääsisi kovin paljon rajoittamaan ihmisen tahdonvapautta. Stoalaisten tavoitteena oli järkiperäinen mielentyyneys, joskaan he eivät tyystin kiistäneet tunteiden merkitystä ihmisen hyvinvoinnille. Aristoteleen filosofian ympärille kasvanut peripateettinen koulu oli suvaitsevaisempi. Sen edustaman kannan mukaan affekteja ja passioita tuli aktiivisesti viljellä ja elvyttää, koska ne eivät sinänsä olleet vahingollisia ihmiselle. Niitä piti käsitellä oikein. (Ks. Sarjala 2001, 88, 120, 123.) Peripateettiseen näkemykseen törmää myös Johann Matthesonin teoksessa Der vollkommene Capellmeister (1739/ 1991 Erster Theil, 15): ’Siellä, missä ei esiinny passioita tai affekteja, ei ole myöskään hyveitä. Jos passiomme ovat tulleet sairaiksi, ne on parannettava, ei murhattava". Myös Turun Akatemian oppineet ja ylioppilaat puolustivat käsitystä, että moraali perustuu viime kädessä ihmisen affektiivisuuteen ja kykyyn kokea tunteita. 
Koska affektit olivat yhtä paljon ruumiillisia kuin mentaalisia tosiasioita, niiden käsittely musiikin avulla oli osa ruumiin poliittista teknologiaa. Keinot ja menettelytavat eivät vain olleet niin näkyviä ja kovakouraisia kuin ne tavat, joita Michel Foucault tai monet muut historioitsijat hänen jäljessään ovat tutkineet. Simo Knuuttila (1998, 32) on todennut, että käsitys ihmisestä olentona, jota ulkoiset vaikutteet ohjasivat likipitäen kausaalisesti, oli tyypillinen esimodernille aikakaudelle ja tuolloin kehitetyille valtioteorioille. Esivallan oli kyettävä tarttumaan affektiiviseen vaikutusketjuun. Myös René Descartesin passioteoria (Les passions de l'âme, 1649) on myöhemmin tulkittu ihmisen sieluruumiin hallintatapojen kehittelyksi, jossa tunteiden ja mielenliikkeiden yksilötasolla tapahtuva kontrolli palveli valtioruumiin hallintaa. Se esitti yksilötasolla mallin järjestyneestä yhteiskunnasta. (Lempa 1993, 28-29.) Tunteita pyrittiin säätelemään yksityiskohtaisesti. Tämä on tausta sille, että myös musiikkia koskien uuden ajan alkupuolen oppineet loivat teoriaa siitä, miten sävelissä, rytmeissä ja harmonioissa piilevät voimat ja liikkeet vaikuttivat ruumiin mikromekaniikan tasolla ihmiseen (ks. lähemmin Sarjala 2001, 94, 96, 100-103, 106-107, 134, 233-234).

Musiikki ei niinkään palvellut politiikkaa kuin oli sitä. Tämä on luettavissa turkulaisten professorien, dosenttien ja ylioppilaiden laatimien akateemisten opinnäytteiden ja Turun Soitannollisen Seuran juhlapuheiden otsikoista: Dissertatio philosophica de usu musices morali (Filosofinen dissertaatio musiikin moraalisesta hyödystä, 1763), Dissertatio Academica De Arcto Musices cum ingenio humano nexu, ejusque ad hoc excolendum momento (Akateeminen dissertaatio musiikin läheisestä yhteydestä ihmismieleen ja merkityksestä sen kehittämisessä, 1791), Om musikens verkan på en nations seder och tänkesätt (Musiikin vaikutuksesta kansakunnan tapoihin ja ajattelutapaan, 1791) tai Om musikens inflytande på människans sedliga känslor (Musiikin vaikutuksesta ihmisen siveellisiin tunteisiin, 1807). Nämä esitykset, joiden otsikot olen poiminut näytteiksi suuremmasta joukosta, ovat todisteita pyrkimyksistä oikeuttaa teoreettisesti tietynlaista halun säätelyn sosiaalista mekanismia. Oppineiden, opiskelijoiden, teinien, kirkonmiesten ja tulevien virkamiesten maskuliinisessa maailmassa musiikkiin ja moraaliin keskittynyt tiedonmuodostus loi standardeja, joita noudattamalla yksittäisistä ihmisistä tuli subjekteja - havaitsemisen, kokemisen ja toiminnan hyväksyttäviä yksiköitä. Esivalta ja sen instituutiot, Turun Akatemia muiden ohessa, pyrkivät istuttamaan yksilöihin tapoja havaita, kokea ja toimia. Olen tarkastellut monografiassani, millaisten olettamusten ja ennakkokäsitysten varassa akateemis-pedagoginen ja kirkollinen valtarakennelma muokkasi kohteitaan, opiskelijoita ja teinejä, määrätynlaisten toimintatapojen kantajiksi, tiettyjen tunnereaktioiden ja tunteenkäsittelytapojen ylläpitäjiksi. Samantyyppinen normittaminen, edellistä tosin hienovaraisempi ja sukupuolisesti vivahteikkaampi, toistui Turun Soitannollisen Seuran kohdalla 1700- ja 1800-luvun vaihteen molemmin puolin.

Uuden ajan alkupuolen musiikkifilosofia loi teoriaa subjektista, ihmisestä toimijana ja toiminnan kohteena olevana kokemusten kantajana. Latinankieliset verbit patere 
(olla alttiina) ja pati (kärsiä) luonnehtivat tuolloin suhdetta musiikin ja kokijan välillä. Musiikki siis määrittyi suhteen kautta, ei itsenäisenä aineksena tai alueena. Tässä valossa valtaosa modernin ajan musiikkitieteestä näyttää yksipuoliselta. Musiikkialan laitosten kirjahyllyistä ja musiikkia koskevista tietokannoista löytyy nykyään massoittain tutkimuksia, artikkeleita ja muita esityksiä, joissa tarkastellaan ja analysoidaan musiikin rakenteita ja muotoja, ylipäänsä soivaa ainesta ja sen ominaisuuksia. Musiikkitieteilijät ovat myös tarkentaneet näkökulmaa tämän aineksen valmistamiseen ja esittämiseen, säveltäjien ja muusikoiden työhön. Halukkaat ovat voineet lukea yhä uusia analyyseja ja tulkintoja samoista kaanoniin kuuluvista teoksista. Tutkijat ovat kehittäneet teorioita ja malleja sävelsuhteista ja harmonioista, soundista, soivan aineksen käsittelystä eri tekniikoin ja keinoin jne. Kieli ja kategoriat, joilla tieteentekijät ovat musiikista puhuneet ja kirjoittaneet, ovat kehittyneet pääosin musiikin valmistamista, rakentumista ja sen "omia" ominaisuuksia koskevan tiedonmuodostuksen pohjalta. Ihmiset ovat aina osanneet puhua ja keskustella eri musiikeista ja niiden aikaansaamista kokemuksista monin tavoin, mutta tutkijat ovat kelpuuttaneet vain harvat puhetavat arvovaltaisen tieteen kentille.

Kuinka paljon musiikintutkimuksen olisi syytä korvata tietoa soivasta aineksesta ja sen ominaisuuksista tiedoilla ja pohdinnoilla halun aikaansaamisesta, ylläpitämisestä ja kanavoinnista musiikin avulla? Tämän tehtävän tarkastelussa ja toteuttamisessa riittäisi tutkijoilla työtä. Silloin akateeminenkin tiedonmuodostus osallistuisi mielekkäällä tavalla yhteiskunnallisesti laajaan ja alati käynnissä olevaan poliittiseen toimintaan, yksilöiden aktiviteetin ja halullisuuden muokkaamiseen musiikissa. Toki tutkijat ovat tätä jo tehneet, Suomessakin. Se on kuitenkin vasta alkua. Ihmisten arkipuheesta ja halun kokemuksista liikkeelle lähtien on mahdollista kehittää uutta kieltä ja kielioppia musiikin hahmottamiseen ja kuvaamiseen. Samalla tavoin toimivat rakenne- ja muoto-orientoituneen musiikinteorian kehittäjät, jotka loivat 1800-luvulla uuden kielen ja terminologian omaan käyttöönsä.

Nykyään affektioppi elää yleistajuisessa muodossa ja intuitiivisella tasolla sekä elokuvamusiikissa että populaarimusiikin monissa lajeissa rockista tangolavoille. Taidemusiikin estetiikka on pyrkinyt karkottamaan affektit konserttisaleista; musiikkitiede on ajanut ne ulos luentosaleista. Mutta muualla musiikin tunnevaikutuksia ja mielihyvää ei ole tarvinnut hävetä. Valkokankailta, televisioruuduista, oopperanäyttämöiltä, rock-konserttien esiintymislavoilta tai kirkoissa lauletuista virsisävelmistä kantautuu korviin jatkuvana virtana tunteita kuvaava ja herättävä musiikki. Näistä suunnista löytyy myös lupaavia tutkimusaiheita musiikin affekteista kiinnostuneille. Toinen mahdollisuus on sukeltaa historiaan. Vaikka vanhat turkulaiset dissertaatiot ja juhlapuheet ovatkin useissa suhteissa outoja tekstejä nykyhetken tutkijalle, hän saa melko pian juonen päästä kiinni lukiessaan, että "musiikki silittelee ihmeellisesti ihmisten sieluja" (Bilmark \& Mechelin 1763, 12). Objektivoinnin ja etäisyyden luomisen tilalla ovat kosketus ja kontaktissa olo. 


\section{Lähteet}

Abert, Hermann 1964. Die Musikanschauung des Mittelalters und ihre Grundlagen. Unveränderter Nachdruck mit einem Geleitwort von Heinrich Hüschen. Tutzing: Hans Schneider.

Alander, Christiern \& Preutz, Samuel 1703. Rhetor musicus, Seu specimen academicum, De vi \& usu Musices In Rhetorica. [Aboae:] Exc. Jo[hannes] Wal[lium].

Bartel, Dietrich 1997. Musica poetica. Musical-Rhetorical Figures in German Baroque Music. Lincoln: University of Nebraska Press.

Bilmark, Johannes \& Mechelin, Johannes Henr[icus] 1763. Dissertatio philosophica de usu musices morali. Aboae: Impressit Joh[annis] Christoph[ori] Frenckell.

Braun, Werner 1994. Affekt. Die Musik in Geschichte und Gegenwart. Zweite, neubearbeitete Ausgabe hrsg. von Ludwig Finscher. Sachteil 1. Kassel \& Basel \& London \& New York \& Prag: BärenreiterVerlag. Palstat 31-41.

Buelow, George J. 1980. Rhetoric and music. The New Grove Dictionary of Music and Musicians, Ed. Stanley Sadie. Vol. 15. London: Macmillan, 793-803.

Buelow, George J. 1983. Johann Mattheson and the invention of the Affektenlehre. New Mattheson Studies, Ed. George J. Buelow \& Hans Joachim Marx. Cambridge: Cambridge University Press, 393-407.

Butt, John 1994. Music Education and the Art of Performance in the German Baroque. Cambridge: Cambridge University Press.

Cusick, Suzanne G. 1994. On a Lesbian Relationship with Music. A Serious Effort Not to Think Straight. Queering the Pitch. The New Gay and Lesbian Musicology, Ed. Philip Brett, Elisabeth Wood \& Gary C. Thomas. New York \& London: Routledge, 67-83.

Descartes, Renatus 1618/1992. Musicae compendium - Leitfaden der Musik. Hrsg., ins Deutsche übertragen und mit Anmerkungen versehen von Johannes Brockt. Zweite, unveränderte Auflage. Darmstadt: Wissenschaftliche Buchgesellschaft.

Frotscher, Gotthold 1926. Die Affektenlehre als geistige Grundlage der Themenbildung J. S. Bachs. Bach-Jahrbuch (23. Jg.). Hrsg. von Arnold Schering. Leipzig: Breitkopf \& Härtel, 90-104.

Gezelius, Johannes 1672. Encyclopaedia synoptica Ex Optimis \& accuratissimis Philosophorum Scriptis collecta, \& in Tres partes distributa. In Usum Studiosæ juventutis, cui neque pretium prolixiores Authores redimendi, neq; tempus eosdem perlustrandi suppetit, Evulgata Curâ \& Sumptibus Johannis Gezelii. Aboæ: Excusa à Johanne Winter.

Goldschmidt, Hugo 1915/1968. Die Musikästhetik des 18. Jahrhunderts und ihre Beziehungen zu seinem Kunstschaffen. Reprografischer Nachdruck der Ausgabe Zürich und Leipzig 1915. Hildesheim: Georg Olms Verlagsbuchhandlung.

Gyllenstålpe, Michael \& Myricius, Ericus Christoph[ori] 1653. Disputatio philosophica De Affectibus Physicè,oratoriè, Ethicè consideratis. Aboæ: Excusa Typis Acad. apud Viduam Petri Wald.

Haartman, Joh[annes Jacobi] \& Kiellgren, Jonas 1732. Dissertatio philosophica De Affectibus Humanis. Aboæ: Excud. R. Acad. Typ. Joh. Kiämpe.

Huhtala, Heikki 1971. Suomen varhaispietistien ja rukoilevaisten sanankäytöstä. Semanttis-aatehistoriallinen tutkimus. Helsinki: Suomalaisen teologisen kirjallisuusseuran julkaisuja LXXXVII.

Kallinen, Maija 1995. Change and Stability. Natural Philosophy at the Academy of Turku (1640-1713). Helsinki: Finnish Historical Society, Studia Historica 51.

Knuuttila, Simo 1998. Järjen ja tunteen kerrostumat. Helsinki: Suomalaisen teologisen kirjallisuusseuran julkaisuja, 215.

Koski, Suvi-Päivi 1996. Geist=reiches Gesang=Buch vuodelta 1704 pietistisenä virsikirjana. Tutkimus kirjan toimittajasta, taustasta, teologiasta, virsistä ja virsirunoilijoista. Helsinki: Suomen kirkkohistoriallisen seuran toimituksia, 172.

Kretzschmar, Hermann 1912. Allgemeines und Besonderes zur Affektenlehre I. Jahrbuch der Musikbibliothek Peters für 1911 (18. Jg.). Hrsg. von Rudolf Schwartz. Leipzig: C. F. Peters, 63-77.

Kretzschmar, Hermann 1913. Allgemeines und Besonderes zur Affektenlehre II. Jahrbuch der Musikbibliothek Peters für 1912 (19. Jg.). Hrsg. von Rudolf Schwartz. Leipzig: C. F. Peters, 65-78.

Laurbecchius, Petrus \& Forzelius, Nicolaus 1680. Dissertatio De Tympanis Magicis. [Aboae:] Impr. a Joh[anne] Waldio, Reg. Univ. Aboëns. Typogr. 
Lempa, Heikki 1993. Bildung der Triebe. Der deutsche Philanthropismus (1768-1788). Turku: Annales Universitatis Turkuensis B 203.

Leppänen, Taru 2000. Viulisti, musiikki ja identiteetti. Sibelius-viulukilpailu suomalaisessa mediassa 1995. Helsinki: Suomen Etnomusikologisen Seuran julkaisuja 6.

Mattheson, Johann 1739/1991. Der vollkommene Capellmeister. Faksimile-Nachdruck hrsg. von Margarete Reimann. 5. Auflage. Kassel \& Basel \& London \& New York: Bärenreiter-Verlag.

McClary, Susan 1991. Feminine Endings. Music, Gender, and Sexuality. Oxford \& Minnesota: University of Minnesota Press.

Rudeen, Torstanus \& Munck, Henricus 1697. Disputatio historico philologica De usu organorum in templis. Aboæ: Impr[essit] apud Jo[hannem] Wallium.

Sarjala, Jukka 2001. Music, Morals, and the Body. An Academic Issue in Turku, 1653-1808. Helsinki: Finnish Literature Society, Studia Historica 65.

Schering, Arnold 1939. Carl Philipp Emanuel Bach und das "redende Prinzip" in der Musik. Jahrbuch der Musikbibliothek Peters für 1938 (45. Jg.). Hrsg. von Kurt Taut. Leipzig: C. F. Peters, 13-29.

Schering, Arnold 1941. Das Symbol in der Musik. Mit einem Nachwort von Wilibald Gurlitt. Leipzig: Koehler \& Amelang.

Schäfke, Rudolf 1924. Quantz als Ästhetiker. Eine Einführung in die Musikästhetik des galanten Stils. Archiv für Musikwissenschaft (6. Jg.), 213-242.

Schäfke, Rudolf 1982. Geschichte der Musikästhetik in Umrissen. 3. Auflage. Tutzing: Hans Schneider. Shepherd, John \& Wicke, Peter 1997. Music and Cultural Theory. Cambridge: Polity Press.

Sponheuer, Bernd 1987. Musik als Kunst und Nicht-Kunst. Untersuchungen zur Dichotomie von 'hoher' und 'niederer' Musik im musikästhetischen Denken zwischen Kant und Hanslick. Hrsg. von Friedhelm Krummacher und Wolfram Steinbeck. Kieler Schriften zur Musikwissenschaft, Band XXX. Kassel \& Basel \& London \& New York: Bärenreiter-Verlag.

Thomas, Downing A. 1995. Music and the origins of language. Theories from the French Enlightenment. Cambridge: Cambridge University Press. 